efforts justified? As those efforts are now set up, both Los Alamos and Lawrence Livermore perform basic design work, while Sandia has a support role - putting together the electronics and other parts of bombs so that they work as planned. Some argue that the country does not need two nuclear weapons laboratories that are doing the same job.

\section{Checks and balances}

DOE and laboratory officials disagree vigorously. "Having two design labs that can balance each other and check each other is very important," says Claytor at DOE. The two laboratories have a history of approaching problems very differently (which is often traced back to the differences and competition between the founding figures Robert Oppenheimer at Los Alamos and Edward Teller at Livermore), and these varying approaches and competitive spirit provide an effective method of peer review in a field that otherwise would have none. "As the number of nuclear tests decreases, the country still has to answer questions about its nuclear forces," says John Nuckols, director of Lawrence Livermore, but with only one lab, there would be no way to settle disputes over weapons design.

The question of whether to pay for two laboratories really depends on how good the United States wants its nuclear arsenal to be, notes Roy Woodruff, formerly associate director for Nuclear Design at Livermore and now a staff scientist at Los Alamos. "If your national policy is minimal deterrence, then one lab may be enough. If you're trying to keep a competitive edge over a very capable adversary, you need something more."

Although Congress answered that question last month by voting the extra $\$ 200$ million to keep nuclear design work healthy at both laboratories, this is unlikely to be the final word. Claytor says he foresees "stability" in the RD\&T budget in coming years, but this is going to be difficult to obtain unless the growing environmental costs level off.

Woodruff says that he, like many nuclear weapons designers, has always hoped that eventually he would work himself out of a job - that nuclear deterrence would hold off war long enough for peace to be kept by other methods, and nuclear weapons would not be needed. Although this seems unlikely to happen soon, still an increasing number of weapons designers could find themselves out of work as the nation decides it has less need to continuously upgrade its arsenal. And one way or another, the laboratories are in for a decade of unprecedented change, and their new courses are going to be set by decisions made in the next couple of years.

Robert Pool

\title{
Will milk shake up industry?
}

\section{Washington}

THE times they are a-changing, down on the farm. Ever since researchers demonstrated the tissue-specific expression of several types of foreign proteins in the milk of transgenic mice, the race has been on to scale up the technology to dairy livestock, where the capacity for highvolume production has obvious appeal.

Now in a significant technological advance, three separate research groups from the United Kingdom, the United States and the Netherlands have made considerable progress in this regard in sheep, goats and dairy cows. The research, reported in the September issue of Bio/Technology,

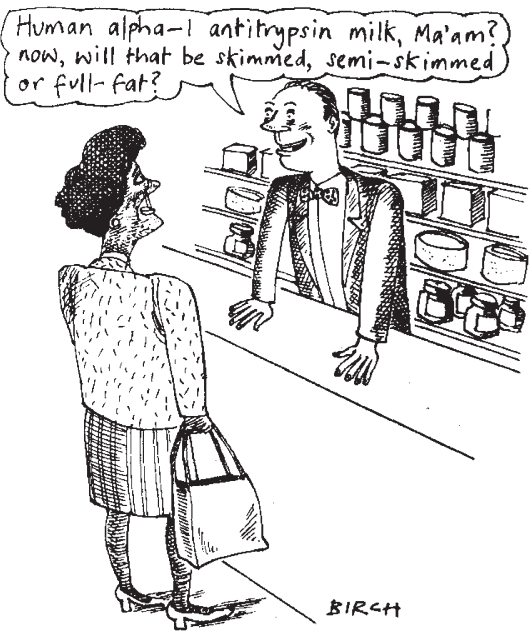

brings the biotechnology industry one step closer to the goal of providing a cheaper means of producing proteins than conventional expression systems.

Success with larger animals was first reported in 1989 by Agriculture and Food Research Council (AFRC) researchers at the Institute of Animal Physiology and Genetics Research in Edinburgh, Scotland. Although the Edinburgh team produced transgenic sheep that secreted human antihaemophilic factor IX and human $\alpha_{1}$ antitrypsin in their milk, expression levels were low.

Building on this, a joint project between Alan Coleman and colleagues at Pharmaceutical Proteins Limited and researchers at the Edinburgh institute produced five transgenic sheep - four females and one male - into which the human $\alpha_{1}$ antitrypsin gene had been incorporated. Following mating and breeding of three of the females, milk from all three contained human $\alpha_{1}$ antitrypsin at levels of greater than 1 gram per litre, and, in one case, levels of up to 35 grams of human $\alpha$ antitrypsin.

Researchers at Tufts University in Massachusetts and at the Massachusettsbased biotechnology company Genzyme Corporation have developed the first transgenic goats to produce tissue plasminogen activator (tPA) in their milk. Although the level of production - about 3 micrograms of tPA per millilitre of milk - is not economically realistic, Karl Ebert, director of experimental biotechnology at Tufts, says he has recently produced another transgenic goat in which the levels were increased a thousand-fold.

From a commercial standpoint, the dairy cow is the animal of choice. Dairy cows can produce 10,000 litres of milk annually, as compared to sheep and goats, whose milk yields can vary from 250 to 800 litres a year, depending on the breed. But historically, efforts to produce transgenic dairy cows have been thwarted because of cumbersome and costly surgical procedures. Now, however, researchers from Gene Pharming Europe (Leiden), the University of Leiden and the Research Institute for Animal Production (Zeist) have circumvented the need for the surgical removal and transfer of embryos by combining gene transfer with an in vitro embryo production system.

Jonathan MacQuitty, president and chief executive officer of GenPharm International, Inc., Gene Pharming's parent company, says GenPharm plans to use the technology to produce hLF, a human milk protein with antibacterial and iron transport properties, for infant formula preparations and as an oral treatment for immunocompromised patients. The company also intends to produce other proteins, which, like hLF, would be difficult or impossible to produce efficiently by other means.

Diane Gershon

\section{TELECOMMUNICATIONS}

\section{Pandolfi boosts HDTV}

\section{London}

IN hopes of encouraging European electronics companies and broadcasters to support new High Definition Television (HDTV) technology, the European Communities (EC) are planning to double their subsidies next year, EC minister for research and telecommunications Filippo Pandolfi announced last week. In a new five-year HDTV strategy that is to begin in 1992 , the $E C$ will spend a total of 1,000 million ecu (\$1,200 million) - 200 million ecu per year - on the broadcasting industry in hopes that a successful launch of HDTV by 1994 will rescue the fading European television and electronics industry. But Pandolfi has an uphill battle for European acceptance of HDTV; a new study by the accounting firm Coopers and Lybrand finds that switching to the new standard will cost consumers 21,000 million ecu $(\$ 25,000$ million) in the next 10 years to upgrade their receiving equipment. Christopher Anderson 